\begin{tabular}{c} 
Volume and Issues Obtainable at Center for Sustainability Research and Consultancy \\
Journal of Accounting and Finance in Emerging Economies \\
ISSN: 2519-0318 ISSN (E) 2518-8488 \\
Volume 2: Issue 2 June 2016 \\
ᄃSRᄃ \\
Journal homepage: www.publishing.globalcsrc.org/jafee \\
\hline
\end{tabular}

\title{
Impact of Asymmetric Information on the Investment Sensitivity to Stock Price and the Stock Price Sensitivity to Investment
}

\author{
${ }^{1}$ Rehana Kouser, ${ }^{2}$ Irum Saba, ${ }^{3}$ Farah Anjum \\ ${ }^{1}$ Professor, Department of Commerce Bahauddin Zakariya University, Multan, Pakistan. \\ rehanakousar@bzu.edu.pk \\ ${ }^{2}$ Assistant Professor, IBA, Karachi Pakistan isaba@iba.edu.pk \\ ${ }^{3}$ MPhil Scholar, Department of Commerce Bahauddin Zakariya University, Multan, Pakistan
}

\begin{tabular}{lr}
\hline ARTICLEDETAILS \\
\hline History & \\
Revised format & May 2016 \\
AvailableOnline & June 2016
\end{tabular}

Keywords

Asymmetric Information

Firm investment

Tobin's $Q$

Stock Prices

Pakistan

JEL Classification:

H32, H39, N55

\begin{abstract}
Purpose: The purpose of the study is to find out the relation between the stock price and investment and to explore the consequence of information asymmetry on the stock price sensitivity to investment and investment sensitivity to the stock prices for the manufacturing firms that are working in Pakistan and listed at KSE.

Methodology: Study was conducted by 99 firms listed at KSE and 1386 observations for the period of 2001-2014. Empirical studies were conducted based on two hypotheses by using price non-synchronous, price delay, firms' size and age as a proxy of asymmetric information and change in asset as a measure of investment.

Findings: Overall results show that there is an insignificant negative correlation between the sensitivity of investment to stock prices and there is an insignificant positive correlation between the sensitivity of stock prices to the investment. The critical findings of the study are that the management must learn from the market during the decision making.

Practical Implications: The research has significant impact on investors, firm management, Government and as well as for the young potential in the field of research.

Originality/Value: The paper fills the research gap. It studies the impact of asymmetric information on the investment sensitivity to stock price, and the stock price sensitivity of investment in Karachi stock Exchange (Pakistan) for the first time.
\end{abstract}

(C) 2016 The authors, under a Creative Commons AttributionNonCommercial 4.0

Corresponding author'semail address:rehanakousar@bzu.edu.pk

Recommended citation: Kouser, R., Saba I., \&Anjum, F. (2016). Impact of Asymmetric Information on the Investment Sensitivity to Stock Price and the Stock Price Sensitivity to Investment.Journal of Accounting and Finance in Emerging Economies, 2 (1) 1-16.DOI:https://doi.org/10.26710/jafee.v2i1.101 


\section{Introduction}

Every investor invests with the aim to maximize his wealth. As we know the management as the agent of the investors work to achieve this basic objective. There are many issues that affects the achievement of this objective. The optimal strategy is developed by the firm to maximize the total worth of the firm that ultimately maximizes the individual investor's wealth. Researchers preach the relationship between the investment and the stock prices. They concluded that the investment and the stock prices are strongly correlated with each other. Two major explanations of the correlation had been presented in literature. The first explanation of this correlation depends on the premise that the share price reflects the information about the firms' fundamentals. Information on the firm's fundamentals impact the manager's investment decision making. When the stock prices reflect the information then we should suppose the positive relation between the investment and the stock prices. Second explanation based on the premise that the firm face the financial limitations that inhibit the firms from their best investment decisions.

In this research paper, we focus on the issue to explore the impact of asymmetric information on the investment sensitivity to stock price and the stock price sensitivity to investment. The collected works in corporate finance have claimed that managers may learn information from the stock price for their investment decisions. Due to the variation in the stock price managers can acquire some information about the future. The prevailing stock price can reflect the different kinds of information about the different market practitioners. A lot of chances are there in which no communication of information between firm and market participants. Information asymmetry has been recognized that it is one of the challenges faced by emerging markets (Murray and Oluba; 2008), and particularly where the market is known as the weak form efficient (Elumilade, 2008).

The market situation, having friction and incompleteness of information identifies as asymmetric information. Basically,the asymmetric information is the gap of information between firm managers and market participants.

In imperfect market, there is an informational gap between insiders and outsiders. Investors react in the market based on available information, while this information is reflected in the stock price. On the other side managers have certain information based on which they must take the investment decisions?

Tobins-Q theory was presented by Tobin (1969) stated that if the capital market is perfect, firm's investment will rely on the ratio market value to book value. When ' $Q$ ' ratio is low ( 0 to 1$)$ it indicates that the replacement cost of assets for a firm is greater than the value of its stock. It refers that the firms' stock is undervalued and the company is not supposed to make any new investment. If the company has the need to acquire equipment, then to acquire second hand equipment is better rather than to acquire new equipment.

When 'Q' ratio is high $(>1)$ it indicates that the value of stock is more than the replacement cost of assets for a firm. It refers that the firms' stock is overvalued. In these situations, the company can make a capital expenditure to purchase new equipment and will make more capital expenditure.

The Ratio is measured through market value of the firm in the asset replacement cost of the firm; it reflects the two different aspects of enterprise valuation. Here in this ratio denominator and numerator represent that, how much the company has the value in the financial market and the replacement cost is? 
How much the company contains the value in the financial market depends upon two things, the company's market value of its stock and market value of its debt. But in the economy and the scenario of Pakistan data regarding replacement cost is not available due to this ratio is calculated as the ratio of the market value of firm to total asset.

Tobin's Q-theory of the investment infers the positive association between the firm stock price and the investment, or alternatively positive relation between investments to stock price firm investment.

In this article, we focused on firm investment, stock prices and the asymmetric information. The purpose of the study is to investigate the relation between the investment and the stock price, impact of asymmetric information on the firm's investment sensitivity to stock price and the sensitivity of stock price to the investment.

\section{Literature Review}

In Boot and Thakor(1997) concluded that investors in the market can be business experts and having more information about the variation in the preferences of customers and the industries. In prevailing condition firm managers have more and better information than the individual investors. Sometime individual investors are more informative than the firm managers based on their investment decisions. This information gap leads towards the variation in market prices. The insider's (management) are more aware about the value of the firm than the potential investors. This act differentiates the shareholders from the management of the firm creates the problems of asymmetric information. And this asymmetric information caused different financial problems for the firm. Because of this, the internal finance becomes cheaper and external finance becomes costlier (Myer \&Majluf, 1987).

When weusedthe relationship between the investment and market friction using the price impact of trade, relative effective spread and the probability of the informed trading (PIN) to measure the information asymmetry and classified the firms as likely constrained, unconstrained and constrained. The firms with greater asymmetric information is highly sensitive to the cash flow based onclassification.Using the PIN, the constrained firm incurs less investment expenditure ascompared to constrained or unconstrained firms (AsliAscioglu, Shantaram\& John B. McDermott, 2007).

Keynesian investment theory, concluded that corporate investment expenditure changes by the alteration in the phases of the business cycle. Investors' expectations about the return tend to fluctuate by the change in the mental nature. This situation is all based on the investors, whether the investor is the optimistic or the pessimistic and based on the investor's perception of the economic condition during the different phases of the business cycle. Different business cycles named as pessimism and optimism. Depression and recession are known as pessimism while the boom and the recovery are known as optimism. Investors spend less during the phase of pessimism while spending more during the phase of optimism.

Studies of the Blanchard et al. (1993) \&Morck et al. (1990) explored the positive relation between the firm investment and the stock price, but these scholars are not agreed on about the reason of the positive relation. Some researchers say that there is negative relation while others say there is positive relationship. In 2007 Chen et.al studies the impact of information in the stock price over the "investment sensitivity to stock price". They concluded that there is a significant positive relation between investment and stock price. The firm's information that is reflected through the price keeps the positive effect about the investment sensitivity to stock price. Further they argued that the firm manager 
performstheir duties to increase the firm value by the decision making will use the information that is available in the market. The information that the firm's managers obtained from the market is not sufficient for the decision making, for the better decision making they must acquire that information which is not present in the market. Accordingly, greater the information that contained in the stock price, greater the firms "investment sensitivity to the stock price" and the firms would be more dependent to the stock prices.

In 2012 Mousavi and Narmin studies the relationship between the Tobins Q ratio and the information asymmetry level to evaluate the performance of the firm. Pearson correlation coefficient used for testing the hypothesis experimentally. They selected firms that were conventional in Tehran Stock Exchange and the data were examined by SPSS software and the EXEL. They concluded that there is no significant relationship between the Tobins Q ratio and the information asymmetry level. Also, they concluded that relationship between the PEPS, EPS and Tobin's Q Ratio is positive.

Kong, Xiao and Liu, (2011) studied the relationship of the "firm's investment and stock price", effect of information asymmetry on the firm's investment sensitivity to stock price and cash flow sensitivity to investment. Researchers had taken 1878 observations regarding 313 companies listed at China stock market. Three different proxies were used as measure of asymmetric information. Initially, R2 which is taken from stock and market returns. Secondly price delay was taken as proxy of asymmetric information, it is also taken from market and stock returns. Thirdly information disclosure score was used, "information disclosure quality scores" was taken from credit files of the Shenzhen Stock Exchange. Capital expenditure is taken as proxy of investment, which is constructed from fixed asset because this is highly correlates to the current investment activities of the firm. Tobin's Q was taken as ratio of the firm's market value to the asset replacement cost. While change in total asset and capital expenditure for investment and Tobin's Q and size, cash flow as control variable. They concluded that during firm investment decisions the manager are learning from the market; asymmetric information keeps the no significant effect on the "firm's investment sensitivity to the stock price". Asymmetric information keeps a significant and positive influence on the "sensitivity of stock price to firm's investment".

Although Chen et al. (2007) find that the synchrony of the stock price in the Western countries is informative, in the stock market of China, studies show that companies with lower R2 are firms whose market's response is not effective enough and companies with lower R2 can make reverse selection to a greater degree, which is different from Western countries (Kong and Shen, 2008). Therefore, in the Chinese stock market, non-synchrony may conversely hold back managers' learning process. With the increase of the information asymmetry, it will be more difficult for the managers to grasp the real situation of the market investors. So, in the situation of high information asymmetry, especially when this information asymmetry reflects noise instead of information, managers will make conservative estimation of market information since information-asymmetry potentially can cause big mistakes or risks. If this situation is real, results will be different from Western countries. Given this argument, with the data from Pakistan Stock Exchange, according to our first objective we want to explore the relationship between firm investment and the stock price, so our first hypothesis is:

$\mathrm{H} 1$ : in presence of asymmetric information there is relationship between the corporate investment and stock prices.

Investors face many problems to assess the firm's behavior toward investment in the presence of market 
friction. As a result, sensitivity in stock price increase with the increase in friction. Wang and Zhang (1998) given the model for principal-agent relation and found that asymmetric information keeps the influence on firm's investment. A theoretical model developed based on different theories of asymmetric information and concluded that asymmetric information has a greater impact on the firm's investment (Cui \& Deng, 2007). When we talk about the real world there are various forces that become the cause of influence. Agency problems and asymmetric information are considered as important element for influencing the corporate investment efficiency (Stein, 2003).

The above discussion compels to construct two more hypotheses to guess the firm's investment pattern considering the investors perception in stock price and change in investors behavior in response to firm investment in the market in the occurrence of the asymmetric information.

H2: Firms investment will response to investor's behavior in price and information disclosure. H3: Investors will response to firm's investment behavior and information disclosure.

\section{Methodology}

\subsection{Data}

All the data in this paper refers to the companies listed at Karachi Stock Exchange for the financial year January 1, 2001 to December 31, 2014. There are two main sources that are used for the fulfillment of the data are the balance sheet analysis and the historical data which is given on the official website of Karachi Stock Exchange. We take only those firms that are listed at Karachi Stock Exchange and excluded those firms that are merged and the unlisted firms. The basic reason to take the listed firms is that we can access only the data of listed companies.

\subsection{Variables of the Study}

\subsubsection{Asymmetric Information (Asyinfo)}

The market condition having friction and the incompleteness of information is called asymmetric information. Basically, asymmetric information is the information gap between the firm managers and the market participants. In 2002 Michael, Akerlof and Stilitz recognized the information asymmetry as an attitude. Various studies are conducted to measure this behavior in the market and to find out the effect of this on many factors. Many of these are to measure the impact of asymmetric information on investment, source of financing and value of stock.

To measure the asymmetric information different measures are used by different researchers. But we took price non-synchronization $\left(1-\mathrm{R}^{2}\right)$, price delay, firm age and firm size as measure of asymmetric information.

Price non-synchronization (1 - R2) is the first measure used in this study as a measure of information asymmetry. R2 is to detain the idiosyncratic information in the stock prices. Roll (1988) encouraged that the price non-synchronization is linked with the idiosyncratic information. Stock price fluctuate with the new incoming information and this firm specific information is amalgamated in the stock price by two different ways. First way the readjustment of the stock prices on the availability of the idiosyncratic information, such as the change in policies, change in management of the firm, expected future earning, downsizing and current performance etc. Second way is the trend the speculators based on the accumulated and detained idiosyncratic information. Roll (1988) exposed that idiosyncratic price 
fluctuation are not subject to certain new release information. Private information considered very important for the capitalization of the idiosyncratic information. Empirical evidences supported the hypothesis that fluctuations in the firm specific return are imitated less in the noise than the private information.

Morck et al. (2000) verified that the price non-synchronization is greater in those countries that having the established financial market are very few in the developing markets. Investors are highly encouraged in gathering the firm specific information in those countries that are having established financial markets. Due to this motivational factor, idiosyncratic information is reflected in the stock price. Durnev et al. (2003) concluded that there is high correlation between the ability of the stock price to evaluate the future earning and the variation in the firm specific returns. He also supported the argument that the variation in the firm specific return are imitated less in the noise than the private information. Kelley (2005) also resist that low R2 imitate lower transmission proficiency. There is significant relationship between the greater the degree of the asymmetric information and the worst information environment.

The variation in the stock price can be composed by two elements. The first component is the firm's idiosyncratic variation, which measures the systematic variation or the price synchronization. While the second component is the firm specific variation that is used to measure the idiosyncratic information or the price non-synchronization.

$\mathrm{R}_{\mathrm{it}}=\propto_{\mathrm{i}}+\beta_{\mathrm{i}} \mathrm{R}_{\mathrm{m}, \mathrm{t}}+\varepsilon_{\mathrm{it}}$

$\mathrm{R}_{i t}$ : Return of the firm $i$ at time $t$

$\mathrm{R}_{m, t}$ : Value weighted market returns at time $t$

The second measure that is used as proxy of the asymmetric information is price delay. Hou and Moskowitz (2005) firstly proposed this measure that reflect how quickly the market data can be incorporated in the stock price. The aim to make this index is to measure the speed with which certain stocks respond to the market information. The higher asymmetric information, the slower stock prices will respond to the new information, as well as more the price delay. Thus, the price delay is considered as a good measure of the degree of the asymmetric information. Specifically, this measure can be assessed by following regression.

$r_{i, t}=\alpha_{i, t}+\beta_{i} R_{m, t+} \sum \delta^{(-n)} R_{m, t-n+} \varepsilon_{i, t}$

ri,t refers to the returns of the firm I at time $t$, while $\mathrm{Rm}, \mathrm{t}$ is the value weighted index for $\mathrm{t}$ time. According to the arguments of the Hou and Moskowitz (2005), we cannot eliminate the stock itself. By using the estimated coefficient from the regression, we can measure the price delay for each firm at the end of the fiscal year.

$$
\text { Delay }=1-\frac{R^{2} \delta_{i}{ }^{(-R)}=0, \forall \in[1,4]}{R^{2}}
$$

Our tests based on the fiscal year data, we calculate the price delay as Hou and Moskowitz (2005) for each firm at the end of the fiscal year by the estimation of the regression using the daily stock return. Kong and Shen $(2007,2008)$ conducted more research on the China Stock market $R^{2}$ and the price delay index, and they concluded that both are associated to the information environment. 
Third measure that is taken in this study is the size of the firm. Previous studies describe that many studies used the firm size as the measure of asymmetric information (Arsalan-Ayadin, Ozkan, \&Florackis, 2006). In 2004 Ozkan also had used the firm size and found the information asymmetry has less amount of concentration: the corporations having the large size due to the transparent disclosure policies.

Different researchers used the different proxies to measure the firm size as market value of firm, worth of total assets, sales volume and the number of employees etc. in this study we take the total asset of the firm as proxy of the firm's size. Median value is calculated from natural log of the firm size. Firms sizes are compared with median values, the firms having the size of more than median are stated as the large firms and firms having the size lesser than median value are stated as the small size firms.

Firm age is also used as proxy of the asymmetric information. Firm age as proxy of asymmetric information is used by many researchers (Pagano, Panetta \&Zingales 1998). New firms have the lesser access to the external as compared to the older firms. It is very supportive to create a favorable relationship based on credit worthiness and the trust. The firm's ages are calculated from the date of their listing at Karachi Stock Exchange. After taking natural log on the ages median age of the firms is calculated. Based on these median firms are compared and categorized into two categories, having age more than the median are declared as old while firms having age less than median are declared as young firms.

\subsubsection{Investment (I)}

Commonly the capital expenditure denotes all spending of firm's investment activities to take operating assets. Investment denotes to the all the activities of investment that are anticipating for financing (trust management, short term investment etc.,) like the acquisitions, purchasing new equipment's', diversification, R\& D and the joint ventures. In the narrow sense, the capital expenditure denotes the direct financing in fixed assets, containing the spending in acquiring the long term and the intangible assets or in purchasing the fixed assets.

We take the change in assets as proxy of investment. Because investment activities take place to the change of the firm's size. We can take change in asset as good proxy (Kong: 2011). Besides the change in assets of the firms also having the firm's acquisition and the divestiture activities.

\subsubsection{Tobin's $Q$ ratio $(Q)$}

Tobins Q is a ratio that was developed by the James Tobin in 1968 and it was also awarded with the Nobel Prize. He anticipated that the market value of the firms on stock exchange should be same as to their replacement cost.

Ratio is measured through market value of firm to the asset replacement cost of the firm; it reflects the two different aspects of enterprise valuation. Here in this ratio denominator and numerator represent that, how much the company has the value in the financial market and the replacement cost is? How much the company contains the value in the financial market depends upon two things, the company's market value of its stock and market value of its debt. But in the economy and the scenario of Pakistan data regarding replacement cost is not available due to this ratio is calculated as ratio of market value of firm to total asset.

$\mathrm{Q}=(\mathrm{MVE}+\mathrm{PS}+\mathrm{DEBT}) / \mathrm{TA}$

MVE: Market Value of firms Equity 
PS: Liquidating Value of the Preferred stock

DEBT: Long Term Debt (Book Value), Short Term Debt and Short Term (current) Assets

When ' $Q$ ' ratio is low (0 to 1$)$ it indicates that the replacement cost of assets for a firm is greater than value of its stock. It refers that the firms' stock is undervalued and the company is not supposed to make any new investment. If the company have the need to acquire equipment, then to acquire second hand equipment is better rather than to acquire new equipment.

When ' $Q$ ' ratio is high $(>1)$ it indicates that the value of stock is more than the replacement cost of assets for a firm. It refers that the firms' stock is overvalued. In these situations, the company can make capital expenditure to purchase new equipment and will made more capital expenditure.

Here we calculated the MVE by multiplying the market price per share (MPS) with the total number of common shares outstanding (\# of CS).

MVE $=$ MPS $\times \#$ of CS

Because of not having the culture of preferred shares in the economy of Pakistan, the liquidating value of preferred shares is zero.

DEBT is calculated by adding up the value of fixed liabilities (FL) and short term (current) liabilities (CL) and then subtracting the value of short term (current) assets (CA).

$\mathrm{DEBT}=\mathrm{FL}+\mathrm{CL}-\mathrm{CA}$

Total assets (TA) are the sum of current assets and the book value of the fixed assets.

$\mathrm{TA}=\mathrm{CA}+\mathrm{NFA}$

NFA: Net or the Book Value of the Fixed Assets

Net of fixed assets refers to the value of total fixed assets after deducting the total accumulated depreciation of fixed assets.

It was considered to determine the probabilities of the other control variables to minimize the chances of the unrelated deviation (Cannon, 2008).

Different researchers used different variables as control variable. Based on the previous studies on the relation between the investment and the stock price by Xiao, Kong and Liu in 2011 used the Future return measure (RET), Cash flow measure (CF), Institutional ownership measure (Insti-own), Market capitalization measure ( $\log (\mathrm{Size})$, and Managerial private information measure (Manager Info) as control variable. In this study, we took $\mathrm{CF}$ and the market capitalization (Log (Size) variables as control variable.

\section{Cash flow}

If capital market were not monitoring the investment opportunities appropriately and were imperfect then according to the Fazzariet all. (1988) the relationship between the internally produced fund and the investment would be positive. In 2007 Chen et all. Concluded that firm's investment is positively impacted by the internally generated funds. In this study, the control variable cash flows are measured as the summation of depreciation and operating profits.

\section{Market capitalization}

Various studies have documented that the company's size will have an important impact in corporate finance research. Therefore, we use the market capitalization as control variable. We use the Log (Size) as the nature logarithm value of the market capitalization at the end of the prior fiscal year.

\section{Institutional Ownership measure (Log (size)}


Literature shows that the institutional ownership has major influence on the stock price and the corporate government (Hou and Moskowitz, 2005; Chan and Hameed, 2006).

Thus, we take the institutional ownership as control variable.

\section{Empirical Model}

After glance over the various literature on the "corporate investment" to test the above hypothesis of this study, considering many alternatives for the empirical models that was collected with empirical and the theoretical justification. These models encourage us to formulate the following econometric models:

$\mathrm{I}_{\mathrm{it}}=\alpha+\beta_{1} \mathrm{Q}_{\mathrm{it}-1}+\beta_{2}\left(\right.$ Asy-info $\left._{\text {it- }-1} * \mathrm{Q}_{\mathrm{it}-1}\right)+\beta_{3}$ ContVars $+\varepsilon_{\mathrm{it}}$

$\mathrm{Q}_{\mathrm{it}}=\alpha+\beta_{1} \mathrm{I}_{\mathrm{it}-1}+\beta_{2}\left(\right.$ Asy-info $\left._{\mathrm{it}-1} * \mathrm{I}_{\mathrm{it}-1}\right)+\beta_{3}$ ContVars $+\varepsilon_{\mathrm{it}}$

$\mathrm{I}_{\mathrm{it}}$ mentions to the firms' investment in fixed assets like, equipment, plant and machinery, land and building for the firm $i$ at time $t$. Investment is measured by taking change in asset, (CHGASSET) that includes the firms acquisition and divestiture activities, $Q_{i}$ is the Tobin's $Q$ ratio presented by James Tobin in 1968 to evaluate the performance of the firm, for the firm $i$ at time $t . \mathrm{Q}_{\mathrm{it}-1}$ is lag of $\mathrm{Q}_{\mathrm{it}}$ for year 1 . Asy-info $_{i t}$ is in use as proxy of asymmetric information dominant in the market that influences the investors decisions' as well as the firms' investment decisions. $\left(1-\mathrm{R}^{2}\right)$ this is price non-synchronization, wherever $\mathrm{R}^{2}$ capture this information contained in assets prices. Asy-info $\mathrm{i}_{\mathrm{it}-1}$ is lag value of the Asy-info it $_{i t}$ for year 1. Market capitalization and CF are taken as the control variables. CF refers to cash flows of the firm (which is measured by the summation of depreciation expense and operating profit). Finally, $\varepsilon_{i t}$ denotes to the error terms in the model.

$\mathrm{Q}_{\mathrm{it}}$ is the ratio that was presented by James Tobin in 1968 to measure the firm performance. It measures the investor's behavior by capturing the "sensitivity of the stock price". It denotes the firms' investment in fixed assets like, equipment, plant and machinery, land and building for the firm $i$ at time $t$. Investment is measured by taking change in asset, (CHGASSET) that includes the firms acquisition and divestiture activities, $\mathrm{I}_{\mathrm{it}-1}$ is lag of $\mathrm{I}_{\mathrm{it}}$ at the year 1 . Asy-info ${ }_{i t}$ is in use as proxy of asymmetric information dominant in the market that influences the investors decisions' as well as the firms' investment decisions. $\left(1-\mathrm{R}^{2}\right)$ this is price non-synchronization, wherever $\mathrm{R}^{2}$ capture this information contained in assets prices. Asy-info $\mathrm{it}_{\mathrm{i}-1}$ is lag value of the Asy-info ${ }_{i t}$ for year 1. Market capitalization and CF are taken as the control variables. CF refers to cash flows of the firm (which is measured by the summation of depreciation expense and operating profit). Finally, $\varepsilon_{\mathrm{it}}$ denotes to the error terms in the model.

To measure the asymmetric information different measures are used by different researchers. But we took three different proxies to measure the asymmetric information. The first proxy that is used in this study is price non-synchronization $\left(1-\mathrm{R}^{2}\right)$, the. The second measure that is used as proxy of the asymmetric information is price delay. Hou and Moskowitz (2005) firstly proposed this measure that reflect how quickly the market data can be incorporated in the stock price. Third measure that is taken in this study is the size of the firm. Previous studies describe that many studies used the firm size as the measure of asymmetric information (Arsalan-Ayadin, Ozkan, \&Florackis, 2006). Firm age is also used as proxy of the asymmetric information. Firm age as proxy of asymmetric information is used by many researchers (Pagano, Panetta \&Zingales 1998). 
Results of empirical tests Descriptive statistics

\begin{tabular}{|l|l|l|l|l|l|l|l|l|l|}
\hline & $\mathbf{I}$ & $\mathbf{Q}$ & $\mathbf{R}^{\mathbf{2}}$ & Age & Size & Delay & $\mathbf{C F}$ & Log(size) & Insti_own \\
\hline Mean & 10.8313 & 1.2528 & 0.8052 & 0.49783 & 0.5 & -2.959 & 745.85 & 6.7219 & 64.9843 \\
\hline Std. Dev & 15.6993 & 0.8098 & 0.3038 & 0.5002 & 0.5002 & 5.581 & 1020.73 & 2.2414 & 28.0728 \\
\hline Min & -7.4006 & 0.4678 & 0 & 0 & 0 & -17.72 & -1.9 & 0.3365 & 0 \\
\hline Max & 43.3589 & 4.7324 & 1 & 0 & 1 & 0 & 3141.6 & 11.5871 & 158.68 \\
\hline $\mathbf{2 5 \%}$ & -0.1321 & 0.7938 & 0.7795 & 0 & 0 & -2.052 & 55.7 & 5.05 & 40.4 \\
\hline $\mathbf{5 0 \%}$ & 5.1055 & 0.9978 & 0.9413 & 0 & 0.5 & -0.248 & 258.5 & 6.8316 & 69.125 \\
\hline $\mathbf{7 5 \%}$ & 19.2238 & 1.3699 & 0.9944 & 1 & 1 & -0.044 & 914.2 & 8.3818 & 91.39 \\
\hline
\end{tabular}

Table 1: Overview of sample

Our sample includes 1386 observations of 99 listed firms of Pakistan Stock Exchange for the period of 2001 to 2014. Table 1 shows the descriptive statistics of the model. The statistics table explains the mean value, standard deviation, minimum value, maximum value and the percentile at $25 \%, 50 \%$, and $75 \%$ level in the data about all measures used in the study, as change in asset (INV), Tobin's Q (Q), Asymmetric information (ASy-info (1-R2), Age, size and price delay), firms level of available cash flow $(\mathrm{CF})$, market capitalization and the institutional ownership. In the table of the descriptive statistics mean denotes to the average value of the data and the standard deviation denotes to the deviation from their mean value. The mean value of the $1-\mathrm{R}^{2}$ is 0.805 it means that the market returns are explaining the change in stock returns twenty percent. When the average amount of size, age and the price delay is $0.4978,0.5$ and -2.9587 .

\section{CORRELATION}

Table 2: Correlation

\begin{tabular}{|l|l|l|l|l|l|l|l|l|l|}
\hline & I & Q & Age & Size & Delay & CF & Log(size) & Inti_own & $\mathbf{R}^{2}$ \\
\hline I & 1 & & & & & & & & \\
\hline Q & 0.0431 & 1 & & & & & & & \\
\hline Age & 0.0315 & 0.136 & 1 & & & & & & \\
\hline Size & 0.1067 & -0.0353 & -0.0227 & 1 & & & & & \\
\hline Delay & 0.0158 & -0.0066 & 0.07 & 0.1676 & 1 & & & & \\
\hline CF & 0.1106 & 0.2084 & 0.0685 & 0.5844 & 0.198 & 1 & & & \\
\hline Log(size) & 0.2144 & 0.3226 & 0.1503 & 0.6557 & 0.1916 & 0.6983 & 1 & & \\
\hline Inti_own & 0.0073 & 0.0607 & -0.1378 & 0.0281 & -0.0172 & -0.0786 & 0.0183 & 1 & \\
\hline $\mathbf{R}^{\mathbf{2}}$ & 0.0573 & 0.0744 & -0.1228 & 0.0509 & -0.3294 & -0.0686 & 0.1233 & 0.055 & 1 \\
\hline
\end{tabular}

Table 2 is containing the correlation matrix that explains the existing relationships among the variables 
that are being used in this study. The correlation of the variables was calculated by the formula of Spearman coefficient of correlation. There is no issue of multicollinearity among the variables, the reason is that correlation coefficient among the variables are less than the 0.9. The correlation among Asy-info $_{\text {it }}$ and is high (0.1233) and its correlation is positive with INV, Q (Tobin's Q), size, market capitalization and the institutional ownership, while it negatively correlated with age, price delay and cash flow.

\section{TEST ON SENSITIVITY OF FIRM INVESTMENT TO STOCK PRICE}

\section{Sensitivity of Firm Investment to Stock Prices}

Table 3

\begin{tabular}{|c|c|c|c|c|c|c|c|c|}
\hline \multirow{3}{*}{$\begin{array}{l}\text { Variables } \\
\mathbf{Q}\end{array}$} & \multicolumn{8}{|c|}{ Change in Asset } \\
\hline & \multicolumn{2}{|c|}{1} & \multicolumn{2}{|c|}{2} & \multicolumn{2}{|l|}{3} & \multicolumn{2}{|c|}{4} \\
\hline & $\begin{array}{c}-1.336 \\
(1.727)\end{array}$ & 0.77 & $\begin{array}{c}-1.408 * \\
(0.794)\end{array}$ & 1.77 & $\begin{array}{c}1.328 \\
(1.029)\end{array}$ & 1.29 & $\begin{array}{c}0.580 \\
(1.067)\end{array}$ & 0.54 \\
\hline $\mathbf{R} 2 * \mathbf{Q}$ & $\begin{array}{c}0.961 \\
(1.893)\end{array}$ & 0.51 & & & & & & \\
\hline $\mathbf{R 2}$ & $\begin{array}{c}0.121 \\
(2.647)\end{array}$ & 0.05 & & & & & & \\
\hline $\mathbf{C F}$ & $\begin{array}{c}-0.000982 \\
(0.000625)\end{array}$ & .157 & $\begin{array}{c}-0.00105 \\
(0.000657)\end{array}$ & .1 .6 & $\begin{array}{l}-0.00102 * \\
(0.000612)\end{array}$ & -1.67 & $\begin{array}{c}0.000494 \\
(0.000998)\end{array}$ & 0.49 \\
\hline $\log ($ Size $)$ & $\begin{array}{c}1.874 * * * \\
(0.298)\end{array}$ & 6.28 & $\begin{array}{c}2.232 * * * \\
(0.336)\end{array}$ & 2.2317 & $\begin{array}{c}1.922 * * * \\
(0.293)\end{array}$ & 6.56 & $\begin{array}{c}2.319 * * * \\
(0.611)\end{array}$ & 3.8 \\
\hline Insti_own & $\begin{array}{l}1.78 \mathrm{e}-05 \\
(0.0165)\end{array}$ & 0 & $\begin{array}{l}0.00145 \\
(0.0165)\end{array}$ & 0.0014 & $\begin{array}{c}-0.000561 \\
(0.0166)\end{array}$ & -0.03 & $\begin{array}{c}0.0222 \\
(0.0337)\end{array}$ & 0.66 \\
\hline Size*Q $^{*}$ & & & $\begin{array}{c}1.267 \\
(1.158)\end{array}$ & 1.09 & & & & \\
\hline Size & & & $\begin{array}{c}-3.639 * * \\
(1.826)\end{array}$ & -1.99 & & & & \\
\hline Age* $\mathbf{Q}$ & & & & & $\begin{array}{c}-2.614 * * \\
(1.216)\end{array}$ & -2.15 & & \\
\hline Age & & & & & $\begin{array}{l}3.015^{*} \\
(1.758)\end{array}$ & 1.72 & & \\
\hline Delay*Q & & & & & & & $\begin{array}{c}-0.0743 \\
(0.102)\end{array}$ & -0.73 \\
\hline Delay & & & & & & & $\begin{array}{c}-0.0332 \\
(0.160)\end{array}$ & -0.21 \\
\hline Constant & $\begin{array}{l}-0.569 \\
(2.771)\end{array}$ & & $\begin{array}{l}-0.802 \\
(2.067)\end{array}$ & & $\begin{array}{l}-2.826 \\
(2.199)\end{array}$ & & $\begin{array}{l}-7.872^{*} \\
(4.555)\end{array}$ & \\
\hline R-squared & 0.0119 & & 0.0139 & & 0.0127 & & 0.018 & \\
\hline
\end{tabular}

This part of the study contains the empirical results. It was explained in detail that this study is basically aimed to analyze the existence of relationship between firms' investment and the stock prices. This part of the study is just to reply the basic questions of the study for which it is conducted. Whether and how information reflected in stock prices (investors' behavior) impacts the management decision making 
process. Table 3, column 1 is reflecting the negative correlation between the investment INVit and Q i,t1 with the coefficient -1.3364 that is showing the insignificant t stat $(-0.77)$ at 5 percent level of significance. Similarly the results of this study are also negating the results concluded by Kong. (2011) and Qi Chen (2005). This result is opposite of Kong, 2011 a study of Shenzen Stock Exchange and Qi Chen (2005) a study of Tehran Stock Exchange, both of these markets are developed and strong market according to the efficient market hypothesis. But the data which are used in this study belong to Pakistan Stock Exchange which is example of weak market.

Furthermore we analyzed the sensitivity of investment to stock price. Results show that the direct effect of price to investment is -1.3364 that shows the negative impact. When we focus on the interaction term Asyt-1* Qt-1 the coefficient is 0.9609 and the 25 percentile value of Asy-info is 0.779464 and median value is 0.9413 . Now at 25 percentile value of Asy-info the total effect of price to firm investment is $1.49191\left[=1.3364-(0.9413-0.77964)^{*} 0.9609\right]$. There is negative relation between the investment and the Asyt-1* Qt-1 that is showing the insignificant $t$ stat (0.51). The results of this study does not support the results concluded by Kong. (2011) and Qi Chen (2005).

Firms cash flows with the coefficient of $-9.80 \mathrm{E}-04$, which is showing insignificant $\mathrm{t}$ stat $(-1.57)$ at 5 percent level of significant. That negate the results of Kong. (2011) and Qi Chen (2005). This negative relationship of investment and cash flow explains that the increase in the level of available cash flow decreases the level of firms' investment and in the same way the decrease in the available cash flow will increase the firm's investment. The correlation between the investment and the market capitalization $[\log ($ size $)]$ is positive with the coefficient value of 1.873 which is showing significant $t$ stat (6.28) at 1 percent level of significant. The results of this study are also negating the results concluded by Kong (2011). This positive relationship between the market capitalization and the firm's investment shows that with the increase in the level of market capitalization leads to the increase in the level of firms' investment. In the same way decrease in the market capitalization leads to the decrease in firm's investment. The relationship between the investment and the Insti_own is positive with the insignificant t stat (0). The results of this study does not support the results of previous researchers like Kong (2011). In table 3, except column 2 all the results shows that there is insignificant positive correlation of investment and price. From column 2 we concluded that there is significant negative correlation of investment and price that shows asymmetric information has significant diminishing impact on the investment sensitivity to the stock price.

According to the Keynesian investment theory, the firms' investment expenditures fluctuate due to the changes in the various business cycle phases. The investors' returns expectations fluctuate with the mental nature of the investors. All this is based on the investor whether investor is pessimistic or optimistic and how investor perceives the economic conditions during different phases of business cycle. Different business cycle phases are named as optimism and pessimism. Boom and recovery stages of business cycle are named optimism and depression and recession are named as pessimism. Investors use more during the phase of optimism and are spendthrift during the phase of pessimism. According to this theory Pakistani manufacturing industry is passing through the recession or depression phases of business cycle. P-value of $F(0.000)$ is showing the overall significance of the model. The findings of the study are similar with the findings of Kong et al. 


\section{TEST ON SENSITIVITY OF STOCK PRICE TO FIRM INVESTMENT}

\section{Sensitivity of Firm Investment to Stock Prices}

Table 4

\begin{tabular}{|c|c|c|c|c|c|c|c|c|}
\hline \multicolumn{9}{|c|}{ Tobin's Q } \\
\hline Variables & \multicolumn{2}{|c|}{ (1) } & \multicolumn{2}{|c|}{ (2) } & \multirow{2}{*}{$\begin{array}{c}(3) \\
0.00231 * * \\
(0.00115)\end{array}$} & \multicolumn{3}{|c|}{ (4) } \\
\hline I & $\begin{array}{l}-0.00392 \\
(0.00247)\end{array}$ & -1.59 & $\begin{array}{l}0.000495 \\
(0.00119)\end{array}$ & 0.41 & & 2.01 & $\begin{array}{c}0.000731 \\
(0.000911)\end{array}$ & 0.80 \\
\hline $\mathbf{R} 2 * \mathbf{I}$ & $\begin{array}{l}0.00548^{*} \\
(0.00286)\end{array}$ & 1.91 & & & & & & \\
\hline $\mathbf{R 2}$ & $\begin{array}{c}0.0934 \\
(0.0664)\end{array}$ & 1.41 & & & & & & \\
\hline $\mathbf{C F}$ & $\begin{array}{l}-1.72 \mathrm{e}-05 \\
(2.69 \mathrm{e}-05)\end{array}$ & -0.64 & $\begin{array}{c}-1.64 \mathrm{e}-06 \\
(2.74 \mathrm{e}-05)\end{array}$ & -0.06 & $\begin{array}{l}-2.18 \mathrm{e}-05 \\
(2.80 \mathrm{e}-05)\end{array}$ & -0.78 & $\begin{array}{l}-1.45 \mathrm{e}-05 \\
(2.82 \mathrm{e}-05)\end{array}$ & 0.28 \\
\hline $\log ($ Size) & $\begin{array}{c}0.169 * * * \\
(0.0150)\end{array}$ & 11.23 & $\begin{array}{c}0.217 * * * \\
(0.0165)\end{array}$ & 12.15 & $\begin{array}{c}0.189 * * * \\
(0.0164)\end{array}$ & 11.5 & $\begin{array}{c}0.182 * * * \\
(0.0165)\end{array}$ & 11.3 \\
\hline Insti_own & $\begin{array}{c}-0.000300 \\
(0.000894)\end{array}$ & -0.34 & $\begin{array}{c}-0.000661 \\
(0.000921)\end{array}$ & -0.72 & $\begin{array}{c}-0.000436 \\
(0.000941)\end{array}$ & -0.46 & $\begin{array}{c}-0.000429 \\
(0.000950)\end{array}$ & -0.45 \\
\hline Size*I & & & $\begin{array}{l}-0.000381 \\
(0.00159)\end{array}$ & -0.24 & & & & \\
\hline Size & & & $\begin{array}{c}-0.387 * * * \\
(0.0504)\end{array}$ & -7.6 & & & & \\
\hline Age*I & & & & & $\begin{array}{c}-0.00372 * * \\
(0.00162)\end{array}$ & -2.3 & & \\
\hline Age & & & & & $\begin{array}{c}-0.241 * * * \\
(0.0717)\end{array}$ & -3.36 & & \\
\hline Delay*I & & & & & & & $\begin{array}{c}4.05 \mathrm{e}-05 \\
(0.000146)\end{array}$ & $\begin{array}{c}0.28 \\
-0.50\end{array}$ \\
\hline Delay & & & & & & & $\begin{array}{l}-0.00152 \\
(0.00307)\end{array}$ & \\
\hline Constant & $\begin{array}{l}0.0710 \\
(0.143)\end{array}$ & & $\begin{array}{l}0.0289 \\
(0.124)\end{array}$ & & $\begin{array}{c}0.147 \\
(0.131)\end{array}$ & & $\begin{array}{l}0.0566 \\
(0.129)\end{array}$ & \\
\hline R-squared & 0.1044 & & 0.153 & & 0.115 & & 0.099 & \\
\hline
\end{tabular}

This segment of the study having the empirical results that obtained from the equation 2. This was explained in detail that the aim of this study is to analyze the existence of relation between the corporate investment and stock prices. This part of the study is to reply the basic question of the study for that it is conducted. How the information reflected in the stock prices effects the process of management's decision making.

Table 4 column 1 shows the negative correlation of Qit and INV I,t- 1 with the coefficient -0.0039 , this negative relationship of investment and price explains that the increase in the level of investment decrease the price and in the same way the decrease in the level of investment increase the level of price but when we consider the $t$ stat which is showing insignificant $t$ stat $(-1.59)$ at 5 percent level of significance. Similarly, the results of this study are also negating the results concluded by Kong. (2011). This result is opposite of Kong, 2011 a study of Shenzen Stock Exchange which is developed and strong market according to the efficient market hypothesis. But the data which are used in this study belong to 
Pakistan Stock Exchange which is example of weak market. As it is already given that the available relationship between the firm's investment and standard stock price is captured through the interaction term if Asy-info and INV it. The coefficient of the interaction term is 0.00547 with t stat of 1.91 that is significant at 10 percent level of significant. This is showing that the price non-synchronization has significant impact on sensitivity of investment to price.

Firms cash flow is showing the negative relationship with coefficient of -0.0000172 this negative relationship of cash flows and investment explains that the increase in the available cash flows decrease the level of firm's investment and in the same way the decrease in the available cash flow will lead to the increase in the level of firms' investment but when we consider the $t$ stat which shows the insignificant $t$ stat $(-0.64)$ at 5 percent level of significant. The results of this study are supporting the results concluded by Kong. (2011). There correlation between the market capitalization and firm's investment is positive with the coefficient of (0.1687), which is showing the significant $t$ stat (11.23) at 1 percent level of significant. The results of this study are supporting the results concluded by Kong. (2011). The positive correlation between the market capitalization and the firm's investment explains that the increase in the level of market capitalization will increase the level of firm's investment. In the same way, the decrease in the market capitalization leads to the decrease in the firm's investment. There is negative correlation between the firm's investment and the institutional ownership with the coefficient value of (-0.00029), which is showing the insignificant $t$ stat $(-0.34)$ at 5 percent level of significant. The results of this study are negating the results concluded by Kong. (2011). This relationship of institutional ownership and the firm's investment explains that increase in the institutional ownership decrease the level of investment and vice versa. $\mathrm{P}$-value of $\mathrm{F}$ is (0.000) is showing the overall significance of the model.

In table 4, columns 2 and 4 show that there is insignificant positive correlation of price and investment. From column 3 we concluded that there is significant positive correlation of price and investment. Overall from the results of table 4 , we find that there is insignificant positive correlation between the sensitivity of stock prices to the investment.

\section{Conclusion}

According to the investment theory Tobin's Q play a major role about the firm's investment when the market is perfect. While in case of imperfect market, and there prevails asymmetric information, then many queries arise.Firstly, by the study on the sensitivity of firm investment to stock price, we conclude that managers will learn that from the market while making decision regarding firm investment and there is insignificant negative correlation between firm investment cost and stock price.The test of sensitivity of stock price to investment has shown the insignificant relationship. Results have shown different relationships between investment and price when different proxies to asymmetric information have been used. Similarly, different relationships were concluded with different measures by Kong, Xiao and Liu (2011). 


\section{References}

Ascioglu, A., Hegde, S. P., \& McDermott, J. B. (2008). Information asymmetry and investment-cash flow sensitivity. Journal of Banking \& Finance, 32(6), 1036-1048.

Arslan, Ö.,Florackis, C., \&Ozkan, A. (2006). The role of cash holdings in reducing investment-cash flow sensitivity: Evidence from a financial crisis period in an emerging market. Emerging Markets Review, 7(4), 320-338.

Baddeley, M. (2003). Investment: theories and analysis.

Blanchard, O., Rhee, C., \&Summers, L. (1990). The stock market, profit and investment (No. w3370).National Bureau of Economic Research.

Boot, A. W., \&Thakor, A. V. (1997).Banking scope and financial innovation. Review of Financial Studies, 10(4), 1099-1131.

Blundell, R., Bond, S., Devereux, M., \&Schiantarelli, F. (1992). Investment and Tobin's Q: Evidence from company panel data. Journal of Econometrics, 51(1), 233-257.

Chung, K. H., \& Pruitt, S. W. (1994). A simple approximation of Tobin's q. Financial management, 7074.

Chen, Q., Goldstein, I., \& Jiang, W. (2007).Price informativeness and investment sensitivity to stock price. Review of Financial Studies, 20(3), 619-650.

Cui, P., \& Deng, K. (2007). Asymmetric information,agent-principle,corporate governance, and firms investment. Studies of Economics and Management, 10, 31-40.

Dow, J., and G. Gorton, 1997, "Stock Market Efficiency and Economic Efficiency: Is There a Connection? 'Journal of Finance, 52, 1087-1129.

Durnev, A., Morck, R., Yeung, B. \&Zarowin, P. (2003). Does greater firm-specific return variation mean informed stock pricing? Journal of Accounting Research, 41 (5), 797-836.

Elumilade, D. O. (2008) "Stock Market Efficiency and Economic Growth in Nigeria: An Empirical ReExamination" Winter 2008 Hawaii Global Conference on Business and Finance

Fazzari, S. M., \& Athey, M. J. (1987). Asymmetric Information, Financing Constraints, and Investment. The Review of Economics and Statistics, 69 (3), 481-487.

Fazzari, S. M., Hubbard, R. G., \& Petersen, B. C. (1988). Financing Constraints and Corporate Investment. Brookings Papers on Economic Activity, 141-206.

Furstenberg, G. (1977), “Corporate investment: does market value matter in aggregate?”, Brooking Papers on Economic Activity, Vol. 6, pp. 347-97.

Hou, K. and Moskowitz, T.J. (2005), "Market frictions, price delay, and the cross-section of expected returns", Review of Financial Studies, Vol. 18, pp. 981-1020.

Hayashi, F. (1982), “Tobin's marginal q and average q: a neoclassical interpretation”, Econometrica, Vol. 50 No. 2, pp. 213-24.

Hayashi, F. and Inoue, T. (1991), "The relation between firm growth and q with multiple capital goods: theory and evidence from panel data on Japanese firms", Econometrica, Vol. 59,pp. 732-54.

Kong, D., Xiao, T., \& Liu, S. (2011). Asymmetric Information, firm Investment and Stock Prices. China Finance Review International, 1 (1), 6-33.

Kong, D. and Shen, R. (2008), "Abnormal return and the information in trading", China Management Studies, Vol. 3, pp. 91-112 (in Chinese).

Lang, L.H.P. and Litzenberger, R.H. (1989), "Dividend announcements: cash flow signaling vs free cash flow hypothesis?", Journal of Financial Economics, Vol. 9, pp. 181-91.

Lindenberg, E.B. and Ross, S.A. (1981), “Tobin's Q ratio and industrial organization”, Journal of Business, Vol. 54 No. 1, pp. 1-32.

Morck, R., Shleifer, A., \&Vishny, R. (1990). The stock market and investment: is the market a side- 
show? Brookings Papers on Economic Activity, 2, 157-215.

Mousavi Shiri, NarminEbrahimi (2012). The relationship between information asymmetry and Tobin's $\mathrm{Q}$ in Tehran Stock Exchange, interdisciplinary Journal of Contemporary Research In Business, VOL 4, NO 1

Murray, J. E. (2008). Identifying, separating, and managing asymmetric information in early 20c health insurance.

Pagano, M., F. Panetta, \& L. Zingales. (1998). Why do Companies Go Public? An Empirical Analysis.Journal of Finance, 53, 27-64.

Roll, R. (1988). R2. Journal of Finance, 43, 541-66.

Stein, J., 2003, 'AAgency, Information and Corporate Investment,' in George Constantinides, Milton

Subrahmanyam, A., \& Titman, S. (1999). The going public decision and the development of financial markets.Journal of Finance, 54 (3), 1045-82.

Summers, L.H. (1981), “Taxation and corporate investment: a q-theory approach”, Brookings Papers on Economic Activity, Vol. 1, pp. 67-127.

Tobin, J. (1969), “A general equilibrium approach to monetary theory", Journal of Money, credit and Banking, Vol. 1 No. 1, pp. 15-29.

Wang, Z., \& Zhang, Z. (1998). Asymmetric information and firms investment. Economic Science, 2, 6670 . 